\title{
Determination of Microbial Activity and Quality Traits of Eggs Coated with Propolis
}

\author{
Sezai Alkan ${ }^{1, a, *}$, Ömer Ertürk ${ }^{2, b}$, İsmail Türker ${ }^{3, c}$ \\ ${ }^{I}$ Department of Animal Science, Faculty of Agriculture, Ordu University, 52200 Ordu, Turkey \\ ${ }^{2}$ Department of Molecular Biology and Genetics, Ordu University, 52200 Ordu, Turkey \\ ${ }^{3}$ Department of Animal Science, Faculty of Agriculture, Yozgat Bozok University, 66200 Yozgat, Turkey \\ *Corresponding author

\begin{tabular}{|c|c|}
\hline R T I C L E I N & B S T R A C T \\
\hline $\begin{array}{l}\text { Research Article } \\
\text { Received : 17/02/2020 } \\
\text { Accepted : 15/06/2020 }\end{array}$ & $\begin{array}{l}\text { In this study, eggs were coated with propolis in order to determine its effect on egg quality and total } \\
\text { bacterial count. Effect of storage time prior to propolis coating was also studied. Eggs were obtained } \\
\text { from a local farm, coated with } 0,3,6 \text { or } 9 \% \text { of propolis and stored at } 4^{\circ} \mathrm{C} \text { with a humidity of } 75 \% \\
\text { for } 30 \text { days. } 18 \text { eggs were used for egg quality traits and } 6 \text { eggs were chosen for microbial activity } \\
\text { for each group. Bacteria were recovered with sterile cotton swabs from egg surfaces. Colonies with } \\
\text { different morphology and color were detected. } 11 \text { bacterial species were determined following the } \\
\text { characterization of } 14 \text { isolates. Elevated levels of bacterial counts were detected for fresh eggs, } \\
\text { which were significantly higher than those stored for } 30 \text { days. The quality traits of the fresh eggs } \\
\text { have also been found higher compared with the other groups. It was observed that coating the eggs } \\
\text { with varying concentrations of propolis lead to significant differences in the total bacterial counts } \\
\text { of the eggshells. Moreover, the egg quality traits which decreased with the increase in storage time } \\
\text { have not been further affected with propolis coating. }\end{array}$ \\
\hline
\end{tabular} \\ Storage time
}

\section{Introduction}

Eggs, which are laid by poultry species, have been extensively used as one of the most valuable human foods. Unless species is specified, the term "egg" is stated as hen egg in legal regulations with foods and food hygiene (Tekinsen and Çelik, 1995). Egg is defined as a shelled food, which is obtained from the hens of Gallus gallus var. domesticus and is either directly presented to human consumption or is used for the preparation of egg products (Altan, 2015).

Eggshell can be contaminated with microorganisms either in reproductive organs or after laying. Contamination with reproductive organs often occurs via Salmonella, mycoplasma and several viral factors in ovary. Majority of newly laid eggs are sterile or contain 300 to 500 microorganisms (Mayes and Tekeball,, 1983). Depending on the temperature and humidity, the number of microorganisms can rapidly increase and reach up to 1500-3000 in 15 $\mathrm{min}$ and 20000-30000 in 1 hour. Husbandry conditions, storage time of eggs and hen's age are regarded as the most crucial factors influencing egg quality (Williams, 1992). Quality traits of eggs decrease with increase in storage time (Silversides and Villeneuve, 1994). $\mathrm{pH}$ of a normal egg varies between 7.6 and 7.9, which can increase up to 9.7 with time (Powrie, 1973).

Egg, which contains high quality protein, can rapidly deteriorate and lose its quality when not stored under appropriate conditions (De Campos et al., 2011). Eggs are contaminated with many microorganisms within a short period of time in farms that do not take necessary hygienic precautions. As the cuticle layer has not been fully formed, some of the pores remain open that in turn allow microorganisms to penetrate easily to the internal parts of the eggs (Williams et al., 1968). Bacteria such as Escherichia, Salmonella and Pseudomonas occur on the surface of eggs (Jones et al., 2011). In order to avoid the entry of the microorganisms into the internal side, eggs are coated with various materials before storing. Edible films and coatings can be derived from polysaccharides, proteins, lipids or gums (Saeed et al., 2017). The primary aim of the edible coatings is the prevention of foods from microbial deterioration and physical damages and thus extension of shell life. 
Propolis is a resinous mixture, which is produced by honey bees from tree buds, sap flows, or other botanical sources by mixing saliva and beeswax (Schmidt, 1997). Due to volatile fatty acid composition, it is generally aromatic and varies in color, taste and consistency depending upon botanical origin and the harvest season (Krell, 1996). Antioxidative, antibacterial and antifungal properties (Krell, 1996) of propolis offer a great potential for human health as well as for food technology in food storage.

This study was carried out to investigate the effects of storage time and coating with varying concentrations of propolis on quality traits and total bacterial counts as well as microbial activity of fresh eggs.

\section{Material and Methods}

\section{Preparation of Propolis Extracts}

Propolis samples were donated by Ordu Apiculture Research Institute. Propolis extracts were obtained by mixing $100 \mathrm{~g}$ of propolis in $500 \mathrm{~mL}$ of $95 \%$ ethyl alcohol (Copur et al., 2008). The samples were stored in air-tight glass containers in a dark place at $-20^{\circ} \mathrm{C}$ until use. The propolis extracts were filtered through $45 \mu \mathrm{m}$ membrane filter and then stored at $4^{\circ} \mathrm{C}$ for one week. 3, 6 and $9 \%$ (w/v) solutions of propolis were diluted from the propolis extract using $70 \%$ ethyl alcohol. These solutions were stored in air-tight glass containers and shaken twice daily. Each solution was filtered into a bottle and stored in dark at $-20^{\circ} \mathrm{C}$ until use.

\section{Provision of Eggs and Design of Treatment Groups}

Fresh eggs were obtained from a local farm. 6 eggs were taken for microbial activity and total bacterial counts for each group (30 eggs in total). Additionally, several egg quality traits were determined on 18 eggs for each group (90 eggs in total), which have been chosen randomly. For the determination of total bacterial counts and egg quality traits, the eggs were coated with 3, 6 and $9 \%$ of propolis by simply spraying the propolis solution and stored for 30 days at $4{ }^{\circ} \mathrm{C}$ with a humidity of $75 \%$. For the control groups, the same procedure was followed for the uncoated eggs. Other quality traits were determined in terms of the parameters given below after keeping the eggs at $24^{\circ} \mathrm{C}$ with a humidity of $75 \%$ (Yannakopoulos and Tserveni-Gousi, 1986; Narushin, 2005; Alkan et al., 2013).

Specific weight $\left(\mathrm{g} / \mathrm{cm}^{3}\right)$ : Specific gravity (SG) was determined by the following equation after weighing in air and in distilled water using an analytical balance with 0.01 g sensitivity.

$$
\mathrm{SG}=\frac{\text { Weight in } \operatorname{air}(\mathrm{g})}{\text { (Weight in air }(\mathrm{g})-\text { Weight in water }(\mathrm{g}))}
$$

Yolk index (YI): Yolk index was determined using the equation below after measuring yolk height with a tripod micrometer and yolk diameter with a digital caliper.

$$
\mathrm{YI}=\frac{\text { Yolk height }(\mathrm{mm})}{\text { Yolk diameter }(\mathrm{mm})} \times 100
$$

Haugh Unit $(H U)$ : Haugh Unit was calculated by the equation below using egg weight and albumen height.

$$
\mathrm{HU}=100 \log \left(\mathrm{H}+7.57-1.7 \mathrm{G}^{0.37}\right)
$$

where $\mathrm{H}$ is the albumen height in $\mathrm{mm}$ and $\mathrm{G}$ is the egg weight in $\mathrm{g}$.

$p H: \mathrm{pH}$ was measured in thick albumen section with a $\mathrm{pH}$ meter.

\section{Total Bacterial Counts}

Microorganisms on the shells of the eggs were swept into a solution by sterile swabs under aseptic conditions in a sterile cabin for determining the total bacterial counts of the eggs coated with or without propolis. In order to take into account the influence of propolis, each group of eggs were treated with no propolis (control group) or 3,6 and 9\% propolis solutions. The solution was diluted $1: 10$ by adding $900 \mathrm{~mL}$ of sterile $1 / 4$ ringer's solution to $100 \mathrm{~mL}$ of ringer's solution prior to homogenization. Similarly, ringer's solution was prepared for each group and dilution process was carried out based on $\log 10\left(10^{-1}, 10^{-2}, 10^{-3}, 10^{-4}, 10^{-5}\right.$ and $\left.10^{-6}\right)$. At the end of this process, $100 \mu \mathrm{L}$ of samples from ranging between $10^{-2}$ and $10^{-3}$ dilutions were inoculated on Nutrient Agar and incubated at $28{ }^{\circ} \mathrm{C}$ for 23 days (Thaddeus et al., 2001).

Identification and Characterization of Bacterial Isolates

Biochemical features of the isolates were determined by Vitek ${ }^{\circledR} 2$ Advanced Colorimetry ${ }^{\mathrm{TM}}$ one day after their inoculation onto Nutrient Agar. During this process, great attention was paid to the use of fresh isolates. Gram-negative (GN) gram-positive (GP) and bacillus (BCL) cards were used for the isolates. The isolates were aseptically transferred to $3 \mathrm{~mL}$ saline solutions (water content 0.45 to $0.50 \% \mathrm{NaCl}, \mathrm{pH} 4.5$ to 7.0$)$ in transparent plastic test tubes $(12 \mathrm{~mm} \times 75 \mathrm{~mm})$. The bacteria were inoculated with sterile extract to the saline tubes. A homogenous microbial suspension with an equivalent turbidity to Mc Farland No: 0.50-0.60 was prepared by McFarland equipment. This procedure was repeated for each sample (Verweij et al., 1999). Cell suspensions and subsequent analyses were made according to the recommendations of the manufacturer.

\section{Preparation of Pure Cultures}

After the incubation, each single colony on the Nutrient Agar was identified and colonies different in morphology and color were determined. These colonies were then taken to be inoculated on Nutrient Agar by streak plate method. In this way, pure cultures were prepared. In addition, inoculations were made on eosin methylene-blue lactose sucrose (EMB) Agar and MacConkey Agar. After staining, samples differing in bacterial shape and color were collected as study materials (Benson, 1985).

\section{Statistical Analyses}

Normal distribution control of the data with respect to all traits was made by Kolmogorov-Simirnov Test. Oneway ANOVA was used for the assessment of the traits fulfilling the hypothesis. Tukey Multiple Comparison Test at $5 \%$ significance level was used to determine different means. The data were analyzed by Minitab 16 Statistical Software. 


\section{Results and Discussion}

In the present study, 11 of 14 isolates determined from the shells of fresh eggs by VITEK ${ }^{\circledR} 2$ were characterized and 11 bacterial species were obtained (Table 1). Most of the isolates were gram-positive bacteria such as Granulicatella adiacens, Micrococcus luteus, Staphylococcus vitulinus, Granulicatella elegans, Staphylococcus lentus and Leuconostoc pseudomesenteroides. On the other hand, two gramnegative bacteria (Pantoea spp. and Escherichia coli) have also been detected.

In a previous study, Turtura and Lorenzelli (1994) reported that $75 \%$ of the chicken meats slaughtered and processed for retail sale contained many gram-positive cocci. 10 of the 93 isolates were identified as Aerococcus viridans. These species, which primarily colonize the intestinal tract, may proliferate in other parts of the human and animal body, and are pathogens. The presence of such species is also an indication of the fecal contamination of chicken meats. Nutritional variant streptococci were defined as a new group of streptococci by Frenkel and Hirsch (1961). Granulicatella adiacens is a member of gastrointestinal and urogenital system microflora (Christensen and Facklam, 2001). Khan et al. (2002) isolated erythromycin resistant gram-positive bacteria from the farm wastes. The primary species were Staphylococcus spp., Enterococcus spp., Streptococcus spp. and S. lentus, the latter being one of the species isolated in the present study. In another study, of the 136 coagulase negative staphylococci strains isolated from the healthy or sick people and from the animals like goat, sheep and antelope, 88 strains were Staphylococcus sciuri $(64.7 \%), 35$ strains were $S$. lentus $(25.7 \%)$ and the remaining ones were characterized as Staphylococcus gallinarum (Adegoke, 1986). These species bear the same features of the species isolated and described in the present study.

Kocuria rosea and Micrococcus luteus were isolated from the shell surface of the eggs in the present study. Kaban and Kaya (2007) determined S. cohnii subsp. cohnii most, which was followed by $S$. saprophyticus, Micrococcus luteus and Kocuria rosea in bacons. In the same study, S. xylosus, which is of technological importance, was only isolated from one of the samples. Vidal et al. (2000) reported keratinolytic activity from the strain of Kocuria rosea, which is known as a soil isolate.

Micrococcus luteus is the predominant strain both in broilers and in areas nearby poultry farms (Plewa and Lonc-Copd, 2011). Dermacoccus nishinomiyaensis, which was recorded as the isolate of TB2-1 in the present study, was reported to be present in soil samples (Kamel et al., 1980). In the same study, Kocuria kristinae and Dermacoccus nishinomiyaensis were shown to degrade poly (vinyl alcohol)/poly (vinyl chloride) and poly (vinyl alcohol)/poly (caprolactone) blends films immersed in the solution, indicating that these bacteria can use plastics as carbon source for metabolic reactions. E. coli is a member of the naturally occurring microflora. Verotoxin producing strains of E. coli were first reported in early 1980's to cause infections and hence diseases in humans (Riley et al., 1983). VTEC can cause several health problems including diarrhea related hemorrhagic ulcer, hemorrhagic colitis and hemolytic-uremic syndrome and producing both symptomatic and asymptomatic infections (Tarr, 1995).

Table 1. Morphological properties of bacterial isolates

\begin{tabular}{|c|c|c|c|c|}
\hline Bacterial species & GS & $\mathrm{P}$ & Bacterial shape, Colony shape and color & Lab code \\
\hline Granulicatella adiacens & $\mathrm{P}$ & 97 & Sometimes seen as coccibacillus or rod cells; $0.4-0.6 \mathrm{~mm}$ & TB7-1 \\
\hline Aerococcus viridans & $P$ & 92 & $\begin{array}{l}\text { Forming round, convex and bright colonies; white or } \\
\text { bright white }\end{array}$ & TB20-1 \\
\hline Micrococcus luteus & $\mathrm{P}$ & 97 & Round or oval shape; production of yellow pigment; yellow & TB21-1 \\
\hline Staphylococcus vitulinus & $\mathrm{P}$ & 95 & $\begin{array}{l}\text { Forming clustered cocci; short chain colonies; white or } \\
\text { cream color }\end{array}$ & TB8-1 \\
\hline Kocuria rosea & $\mathrm{P}$ & 98 & 1.0-1.5 mm; slightly convex; smooth; pink & TB12-1-1 \\
\hline Granulicatella elegans & $\mathrm{P}$ & 97 & $\begin{array}{l}\text { Gram-positive with Streptococci morphology; short } \\
\text { chain; white or cream }\end{array}$ & TB22-1 \\
\hline Staphylococcus lentus & $\mathrm{P}$ & 96 & $\begin{array}{l}\text { Forming clustered cocci; colonization of the skin of } \\
\text { different animals; commensal }\end{array}$ & TB5-1 \\
\hline $\begin{array}{l}\text { Leuconostoc } \\
\text { pseudomesenteroides }\end{array}$ & $P$ & 86 & $\begin{array}{l}\text { Gram-positive cocci naturally found in milk products, } \\
\text { vegetables, legumes and sometimes in human feces }\end{array}$ & TB8-1 \\
\hline Pantoea spp. & $\mathrm{N}$ & 93 & 2-3 mm; convex, rod shaped; bright yellow & TB1-1 \\
\hline $\begin{array}{l}\text { Dermacoccus nishinomiyaensis } \\
\text { (Kytococcus sedentarius) }\end{array}$ & $\mathrm{P}$ & 97 & Irregular clusters, short rods; orange & TB2-1 \\
\hline Escherichia coli & $\mathrm{N}$ & 99 & Rod shaped; yellow-amber & TB10-1 \\
\hline
\end{tabular}

GS: Gram, spore; P: Positive; N: Negative; P: Probability (\%)

Table 2. Total bacterial counts on the shells of the eggs

\begin{tabular}{l|c}
\multicolumn{1}{c|}{ Groups } & Total bacterial counts (cfu/egg) \\
\hline Fresh & $67.67 \times 10^{4} \pm 3.38 \times 10^{4 \mathrm{a}}$ \\
Control (30 days storage) & $14.67 \times 10^{4} \pm 2.67 \times 10^{4 \mathrm{~b}}$ \\
$3 \%$ propolis (30 days storage) & $11.33 \times 10^{4} \pm 0.33 \times 10^{4 \mathrm{~b}}$ \\
6\% propolis (30 days storage) & $9.26 \times 10^{4} \pm 0.16 \times 10^{4 \mathrm{~b}}$ \\
9\% propolis (30 days storage) & $9.13 \times 10^{4} \pm 0.03 \times 10^{4 \mathrm{~b}}$ \\
\hline
\end{tabular}


Table 3. Egg quality traits

\begin{tabular}{l|cccc}
\hline \multicolumn{1}{c|}{ Groups } & $\mathrm{pH}$ & Specific gravity $\left(\mathrm{g} / \mathrm{cm}^{3}\right)$ & Yolk index & Haugh unit \\
\hline Fresh & $8.68 \pm 0.03^{\mathrm{a}}$ & $1.0876 \pm 0.0012^{\mathrm{a}}$ & $50.12 \pm 0.73^{\mathrm{a}}$ & $90.11 \pm 1.61^{\mathrm{a}}$ \\
Control (30 days storage) & $9.42 \pm 0.02^{\mathrm{b}}$ & $1.0447 \pm 0.0017^{\mathrm{b}}$ & $34.54 \pm 0.73^{\mathrm{b}}$ & $39.45 \pm 3.41^{\mathrm{b}}$ \\
$3 \%$ propolis (30 days storage) & $9.41 \pm 0.17^{\mathrm{b}}$ & $1.0518 \pm 0.0026^{\mathrm{b}}$ & $35.33 \pm 0.49^{\mathrm{b}}$ & $34.86 \pm 3.65^{\mathrm{b}}$ \\
6\% propolis (30 days storage) & $9.40 \pm 0.01^{\mathrm{b}}$ & $1.0530 \pm 0.0023^{\mathrm{b}}$ & $33.17 \pm 0.75^{\mathrm{b}}$ & $35.70 \pm 3.35^{\mathrm{b}}$ \\
$9 \%$ propolis (30 days storage) & $9.39 \pm 0.05^{\mathrm{b}}$ & $1.0478 \pm 0.0028^{\mathrm{b}}$ & $35.15 \pm 0.66^{\mathrm{b}}$ & $41.86 \pm 3.17^{\mathrm{b}}$ \\
\hline
\end{tabular}

${ }^{\mathrm{a}, \mathrm{b}}$ Different letters in the same column indicate significant differences between groups $(\mathrm{P}<0.01)$

Total bacterial counts on the shells of fresh eggs or the eggs exposed to propolis at varying concentrations are presented in Table 2. After 30 days of storage, bacteria were not detected in the samples from the internal parts of the eggs in each treatment group, indicating that no entry of bacteria into the egg can take place as long as the eggs are stored under suitable conditions. It is worth mentioning that the coating used for the control group contains ethyl alcohol but no propolis.

Microbiological examination of the eggshells in the present study clearly demonstrated that the total bacterial counts in propolis treated groups were lower as compared to the fresh eggs, which received no propolis $(\mathrm{P}<0.01$; Table 2). When we evaluate the total bacterial counts for the control group, we observed that the increase in the storage time resulted in decrease in the number of total bacteria on the shells of the eggs. Moreover, coating of eggs with propolis in a concentration dependent manner resulted in significant decrease in the total bacterial counts of the groups. It was observed that, coating the eggs with $6 \%$ propolis solution resulted in $37 \%$ decrease (from $14.67 \times 10^{4}$ to $9.26 \times 10^{4}$ ) in the total bacterial counts on the eggshells.

Some quality traits of the eggs exposed to different treatments are given in Table 3 . Best quality traits were determined with the fresh eggs, which were significantly higher than the other treatment groups $(\mathrm{P}<0.01$; Table 3$)$. As clearly seen from the table, significant losses in quality traits were detected in all groups after 30 days of storage. Application of propolis at varying concentrations did not lead to any significant changes in quality traits of the eggs.

The $\mathrm{pH}$ ranged between 7.6 and 8.5 in the fresh eggs and increased up to 9.2 and 9.4 as the storage time increased. Specific gravity of normal eggs varies in the rage from 1.065 to $1.100 \mathrm{~g} / \mathrm{cm}^{3}$ (Türkoğlu and Sarıca, 2014). Haugh unit and yolk index of eggs should be greater than 79 and 46, respectively (Türkoğlu and Sarıca, 2014). The $\mathrm{pH}$ and specific gravity of the fresh eggs were found within the acceptable values reported in the literature. High yolk index and Haugh unit values were recorded in the fresh eggs and were consistent with the values in the literature. The values of all quality traits were deviated from those of the fresh eggs when the eggs were stored for 30 days. Especially Yolk index and Haugh unit values decreased very significantly. When the control group was compared with the propolis coated groups, it was observed that the losses in the quality traits after 30 days of storage occurred to the similar extents. So, it is clear that coating of eggs with propolis did not influence the quality traits of the eggs (Table 3). If we compare the results of our study with literature, Copur et al. (2008) coated eggs with ethyl alcohol, 5\%, $8 \%$ and $10 \%$ propolis and stored for four weeks at room temperature $\left(25^{\circ} \mathrm{C}\right)$ and found higher albumen index and Haugh unit values in the eggs coated with $8 \%$ and $10 \%$ propolis as compared to other treatment groups. They also noted that during storage, albumen height decreased whereas albumen $\mathrm{pH}$ increased more in the eggs of the control, alcohol or $5 \%$ propolis groups compared to the eggs of 8 and $10 \%$ propolis groups. The authors suggested that coating of eggs with $10 \%$ propolis extract improved interior egg quality during storage. However, coating with $9 \%$ propolis did not generate similar results. This difference between the study of Copur et al. (2008) and the present study can be explained by the storage temperature $\left(25\right.$ vs $4^{\circ} \mathrm{C}$, respectively) and implies that propolis may be protective at higher storage temperatures.

\section{Conclusions}

In conclusion, great efforts are spent to maintain quality traits of eggs until their use by the consumers. In this regard, studies on the storage methods, which will enable to protect eggs from undesirable factors and to extend their shelf life, are carried out. This study was designed for a similar purpose and investigated the influence of propolis coating and storage of eggs for 30 days on quality and total bacterial counts. The results indicated that propolis application under the conditions of the present study resulted in significant decrease in the total bacterial counts of the eggshells. Moreover, application of propolis at varying concentrations did not lead to any significant changes in quality traits of the eggs.

\section{References}

Adegoke GO. 1986. Comparative characteristics of Staphylococcus sciuri, Staphylococcus lentus and Staphylococcus gallinarum isolated from healthy and sick hosts. Veterinary Microbiology. 11: 185-189

Alkan S, Karslı T, Galiç A, Karabağ K. 2013. Determination of phenotypic correlations between internal and external quality traits of guinea fowl eggs. Kafkas Universitesi Veteriner Fakultesi Dergisi. 19: 861-867.

Altan O (2015). Yumurta - Oluşumu, Kalitesi ve Biyoaktif Komponentleri. İzmir, Turkey: Ege University Press. 978605-84400-0-5.

Benson HJ. 1985. Microbiological Applications: A Laboratory Manual in General Microbiology, 4th ed., Dubuque, Iowa. 007-231888-0.

Christensen JJ, Facklam RR. 2001. Granulicatella and Abiotrophia species from human clinical specimens. Journal of Clinical Microbiology. 39: 3520-3523.

Copur G, Camci O, Sahinler N, Gul A. 2008. The effect of propolis eggshell coatings on interior egg quality. European Poultry Science. 72: 35-40.

De Campos A, Marconato JC, Martinsfranchetti SM. 2011. Biodegradation of blend films PVA/PVC, PVA/PCL in soil and soil with landfill leachate. Brazilian Archives of Biology and Technology. 54: 1367-1378. 
Frenkel A, Hirsch W. 1961. Spontaneous development of L forms of streptococci requiring secretions of other bacteria or sulphydryl compounds for normal growth. Nature. 191: 728 730.

Jones DR, Anderson KE, Musgrove MT. 2011. Comparison of environmental and egg microbiology associated with conventional and free-range laying hen management. Poultry Science. 90: 2063-2068.

Kaban G, Kaya M. 2007. Staphylococcus xylosus ve Lactobacillus plantarum Suşlarının sucuğun duyusal özellikleri ve renk değerleri üzerine etkileri. Atatürk Üniversitesi Ziraat Fakültesi Dergisi. 38: 83-89.

Kamel B, Bond C, Diab M. 1980. Egg quality as affected by storage and handling methods. Journal of Food Quality. 3: 261-273.

Khan AA, Nawaz MS, Khan SA, Steele R. 2002. Detection and characterization of erythromycin-resistant methylase genes in Gram-positive bacteria isolated from poultry litter. Applied Microbiology and Biotechnology. 59: 377-381.

Krell R. 1996. Value-added products from beekeeping. FAO Agricultural Services Bulletin No. 124. Food and Agriculture Organization of the United Nations, Rome, Italy

Mayes FC, Tekeballi MA. 1983. Microbial contamination of the hen's egg: A review. Journal of Food Protection. 46: 10921098.

Narushin VG. 2005. Egg geometry calculation using the measurements of length and breadth. Poultry Science. 84: 482-484.

Plewa K, Lonc-Copd E. 2011. Analysis of airborne contamination with bacteria and moulds in poultry farming: a case study. Polish Journal of Environmental Studies. 20: 725-731.

Powrie WD. 1973. Egg Science and Technology. Stadelman WJ, Cotterill OJ (editors). Westport, Connecticut: The Avi Publishing Company Inc.

Riley LW, Remis RS, Helgerson SD, Mcgee HB, Wells JG, Davis BR, Hebert RJ, Olcott ES, Johnson LM, Hargrett NT, Blake PA, Cohen ML. 1983. Hemorrhagic colitis associated with a rare Escherichia coli serotype. The New England Journal of Medicine. 308: 681-685.
Saeed F, Javaid A, Ahmed N, Nadeem MT, Arshad MS, Imran A, Sohaib M, Khan AU. 2017. Influence of edible coating techniques on quality characteristics of eggs. Journal of Food Processing and Preservation. 41: e12815 doi:10.1111/jfpp.12815

Schmidt JO. 1997. Bee products: chemical composition and application. In: The Bee Products: Properties, Applications and Apitherapy. Mizrahi A and Lensky Y (editors), New York: Plenum Press. p: 15-26. 978-1-4757-9371-0.

Silversides FG, Villeneuve P. 1994. Is the Haugh unit correction for egg weight valid for eggs stored at room temperature? Poultry Science. 94: 50-55.

Tarr PI. 1995. Escherichia coli O157: H7: Clinical, diagnostic, and epidemiological aspects of human infection. Clinical Infectious Diseases. 20: 1-10.

Tekinsen CO, Çelik C. 1995. Yumurta. Konya, Turkey: Selçuk University Faculty of Veterinary Medicine Press.

Thaddeus F, Baryant M, Baryant RG. 2001. Sampling plans, sample collection, shipment, and preparation for analysis. In: Downes F P, Ito K (editors): Microbiological Examination of Foods. 4th ed., American Public Health Association, Washington DC, pp. 13-23.

Turtura GC, Lorenzelli P. 1994. Gram-positive cocci isolated from slaughtered poultry. Microbiological Research. 149: 203-213.

Türkoglu M, Sarica M. 2014. Tavukçuluk Bilimi (Yetiştirme, Besleme, Hastalıklar). Ankara, Turkey: Bey Ofset Matbaacilik.

Verweij PE, Breuker IM, Rijs AJ. 1999. Comparative study of seven commercial yeast identification systems. Journal of Clinical Pathology. 52: 271- 273.

Vidal L, Christen P, Coello MN. 2000. Feather degradation by Kocuria rosea in submerged culture. World Journal of Microbiology and Biotechnology. 16: 551-554.

Williams JE, Dillard LH, Hall GO. 1968. The penetration of patterns of Salmonella typhimurium through the outer structures of chicken eggs. Avian Diseases. 12: 445-466.

Williams KC. 1992. Some factors affecting albumen quality with particular reference to Haugh unit score. World's Poultry Science Journal. 48: 5-16.

Yannakopoulos AL, Tserveni-Gousi AS. 1986. Quality characteristics of quail eggs. British Poultry Science. 27: 171176. 